\title{
IMPACT OF SPATIAL CONFIGURATION TO SPATIAL QUALITY: VENICE AND ISTANBUL
}

\author{
İmran GÜMÜŞ (iD 1,* Ebru ERDÖNMEZ (iD) ${ }^{2}$ \\ ${ }^{1}$ Department of Architecture, Faculty of Architecture and Design, Bursa Technical University, Bursa, Turkey \\ ${ }^{2}$ Department of Architecture, Faculty of Architecture, İstanbul University, Istanbul, Turkey
}

Received 11 February 2021; accepted 27 August 2021

\begin{abstract}
The purpose of this study is to identify the relationship between spatial configuration and spatial quality, and how they affect each other. Spatial quality is a sophisticated concept and encompasses physical, social, economic, cultural and environmental components. Urban squares reflect these parameters and also play a decisive role in urban identity as areas of apparent urban culture and collective memory. Spatial configuration also determines the character of the squares as a result of morphological feature of cities. In the study, qualitative and quantitative methods are used together. Initially, the case study was conducted on two pier squares, San Marco Square (Venice) and Beşiktaş Square (Istanbul) according to fifty public space quality parameters. Secondly, morphological analysis was performed through space syntax method. It has been investigated whether there is a connection between spatial configuration and the factors determining the quality of space or not. As a result, it has been revealed that the spatial configuration is one of the determining factors being assessed the quality of the space, however, it does not provide sufficient data alone. The importance of this article is that it proposes an analytical approach that includes both quantitative and qualitative components of spatial quality.
\end{abstract}

Keywords: spatial quality, urban square, space syntax, urban morphology, Venice, Istanbul.

\section{Introduction}

Public spaces, which are the production area of social interactions constitute the source of communication between individuals with their meanings (Erdönmez \& Ak1, 2005). Streets, parks and squares are the variation of public spaces and they have potential to bring people together. These spaces have economic, political, social and cultural codes of the society (Baytin, 2006) and have political and commercial meanings (Gökgür, 2006) such as mobility, use (festival, concert, sports, commercial use), socialization and identity.

The squares, which are the physical spaces between the dense urban context, encourage socialization, serve the formation of urban identity, which is an expression of the soul of the place (genius loci), and are determinative in urban perception (Schulz, 1971; Lynch, 1960). The squares that reflect the identities and images of the cities contribute to urban life such as creating social memory, increasing activities and socialization. Squares as places that bring people together, increase the quality of life and create a sense of belonging (Walzer, 1986; Mazumdar, 2007) are common spaces where local culture, lifestyle and collective memory are kept alive, social relations are shaped, and daily life activities and rituals are held (Zengel, 2007; Terzi et al., 2019).

Urban morphology affects land use, social communication and interaction level, and human movements. Cities are mechanisms that facilitate communication and social interaction (Hillier, 1996). Therefore, the intensity of use of an urban space is one of the critical indicators for a successful public space. Space syntax theory, developed by Hillier and Hanson at UCL in the 1970s, reveals the effect of the physical qualities of space, the pattern of space on social interaction and spatial experience. Space syntax (SSX) is used as a tool to understand the relationship between pedestrian movement and urban fabric, readability of space, and social structure (Çil, 2006). SSX is an analysis tool that demonstrates the nature of spatial configuration on an architectural and urban scale. Spatial configuration affects human movements and gives information about the social and cultural qualities of cities.

The space syntax method reveals the general characteristics of spatial patterns as well as spatial experience. But this method is not evaluated concerning spatial quality criteria, yet. This research aims to establish a

${ }^{*}$ Corresponding author. E-mail: imran.gumus@btu.edu.tr 


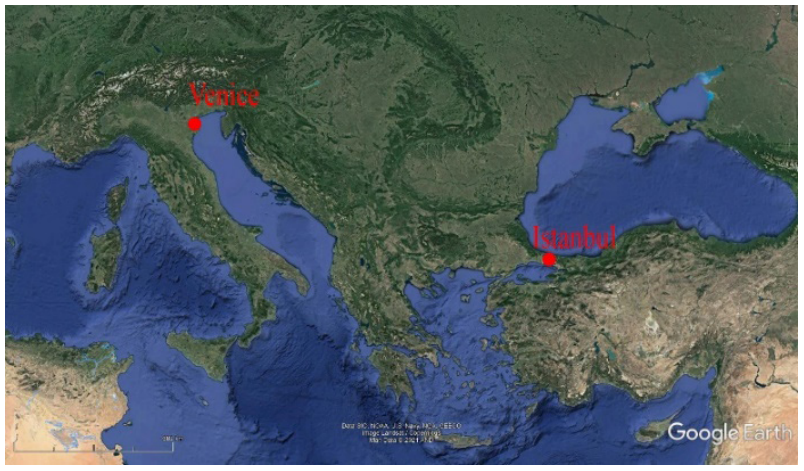

Figure 1. The map, showing Venice and Istanbul (Google Earth)

relationship between space quality parameters and spatial configuration. However, there is no study in the literature that deals with these two concepts together. Spatial quality and spatial configuration of public spaces are different research areas in the literature. The main objective of this research to reveal the relationship between spatial configuration and spatial quality with quantitative and qualitative measurement methods.

Venice and Istanbul, the two important port cities of the Mediterranean geography, have been on the main transportation routes throughout history (Figure 1). "There was a commercial route between Istanbul and Venice along the Adriatic Sea" (Agirbas \& Ardaman, 2015). There are two coastal cities with elevated intercultural interaction. One of them located in the north of the Adriatic Sea, Venice is an island city in Italy. In the city where there is no vehicle entrance, transportation takes place on foot and by sea. The other is Istanbul, which is a city of the Bosphorus and the sea, has a significant location with its Bosphorus geography.

Two pier squares, San Marco Square (SMS) and Beşikaş Square (BS) located at the intersection of land and coast. SMS is one of the city's most magnificent urban spaces. BS, located at the busiest point of the Bosphorus, is a square directly related to the sea, like San Marco. SMS connects mainland with the islands whereas BS connects two continents. Both squares are located in geographically critical points with high levels of pedestrian activity and density. Both squares have witnessed religious ceremonies, huge events and celebrations throughout their history. BS was also the military action center during the Ottoman Period. These two squares, which are one of the liveliest public spaces in the cities in which they are located, are group squares consisting of five different sub-regions (Figure 2). San Marco Square and Beşiktaş Square are used by 10 million visitors per year (Fraser, 2020; Okan University, 2015).

\section{Literature review on spatial configuration and spatial quality of public spaces}

Many studies measuring the effects of spatial configuration on public space (Bendjedidi et al., 2018; Zerouati \&

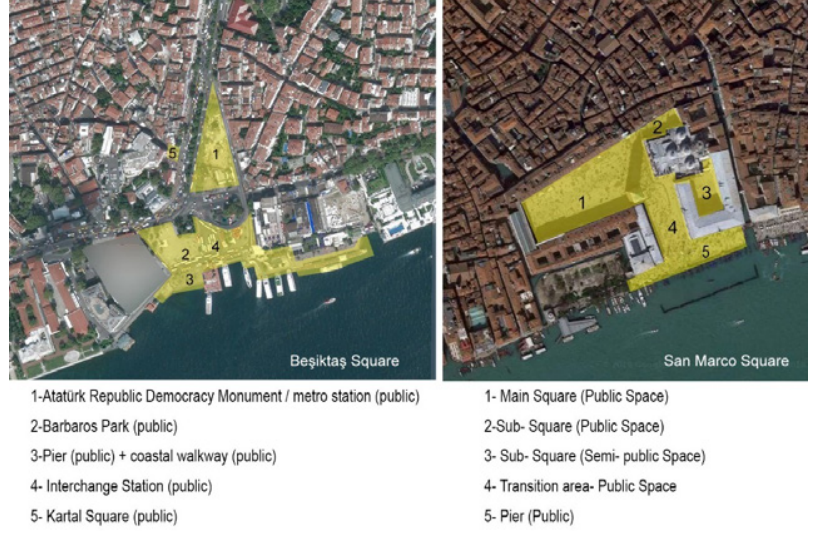

Figure 2. Sub-regions of the squares

Bellal, 2019; Arruda Campos, 1997, 2000; Major et al., $1999,2000)$ provide information on the success and usage density of urban open spaces and squares. Space syntax approach can inform us whether the location of a square in a city context is suitable or not, if the density of transportation axes are feeding a square, whether the square is readable in the city or not, which spatial experience it offers and the density of pedestrian and vehicle mobility (Safari \& Moridani, 2017; Hu et al., 2017). Space syntax also provides important information such as "the social content of spatial patterning and the spatial content of social patterning" (Hillier \& Hanson, 1984, pp. 10-11), socio-spatial setting of urban space (Van Nes \& Yamu, 2018), the character of urban areas (Read, 1999), a visual experience related to the spatial configuration ( $\mathrm{Lu}$ et al., 2019), the relationship between spatial configuration and the degree of resistance of cities (Abshirini \& Koch, 2017).

A successful public space can be defined as an inclusive space with well-defined physical boundaries, enabling interaction, having natural elements such as water, vegetation, landscape where users can participate actively or passively, and can be used by many individuals, children, elderly, and disabled people. The parameters that determine the success of a square are relationship with surrounding buildings (Collins et al., 1986), multi-functionality and distinctive form (Madanipour, 1999), vitality, sense, fit, access and control elements (Lynch, 1981), social interaction capacity (Whyte, 1985), protection, enjoyment and comfort, accessibility (Gehl, 2002, 2010), enabling of active and passive participation, being democratic, responsive and meaningful (Carr et al., 1992) activity, form, image (Montogomery, 1998), comfort facilities, and character.

While some studies in the literature focus on the semantic and conceptual framework and components of spatial quality (Rapoport, 1970; Madanipour, 1999; Moulaert et al., 2013; Khan et al., 2014; Albrechts et al., 2003; Dutta et al., 2013; Brand et al., 2014; Panagopoulos et al., 2016; Javadi, 2016; Commission for Architecture and the Built Environment, 2001) others conducted a quality assessment using field observation, survey and interview techniques (Appleyard \& Lintell, 1972; Das, 2008; Vadiati \& Kashkooli, 2011; Bendjedidi et al., 2019; Nasution \& 
Zahrah, 2012; Yeganeh \& Kamalizadeh, 2018; Zakariya et al., 2014). Some studies comparatively measure the quality of squares and public open spaces with the indexes created by mathematical expression of the variables obtained using survey and observation techniques (Mehta, 2014; Terzi et al., 2019; Praliya \& Garg, 2019). The study on market squares, which is a public space that reflects intense human interaction, has revealed that there is a connection between the built environment, human relations and well-being (Agboola et al., 2018).

\section{Methodology}

A two-step method has been applied in the quality assessment of the SMS and BS. Firstly, the quality parameters chosen based on the literature review are grouped into six different categories. By applying the observation technique, the two squares are quantitatively compared according to the Likert Scale based on a total of 50 different criteria within these six categories.

In the second step, the urban fabric and the pedestrian routes in the squares were analyzed through the SSX, using Depthmap X software. Axial maps of the cities were drawn and then connectivity, global and local integration values were measured over axial maps. Moreover, VGA (visibility graph analysis) and isovist graphics were created. These obtained mathematical measurements were interpreted in accordance with the quality parameters of the squares. SSX data were tested with observational data over two different coastal squares.

\subsection{Creating public space quality parameters score table}

As a result of the literature review, quality parameters were evaluated in six different groups as Location / Form / Visual and Physical qualities; Vitality / Pedestrian Activity; Identity / Image / Sense of place; Comfort; Integrative / Responsiveness; Managerial. To summarize these parameters:

- Squares have been used in different functions from past to present. The relation of the squares with the urban texture, their location, the number and density of the surrounding axles, their form, size (Whyte, 1988; Sitte, 1965/1889; Bacon, 1974) directly affect the usage density and intended use of the squares. The concepts of visual experience, enclosure effect, openness, views on skyline, visibility are important parameters that determine the quality of squares (Cullen, 1961; Alexander et al., 1977; Montgomery, 1998).

- Legibility and imageability concepts are directly related to visual experience as a result of the physical characteristics of squares, as a reflection of the images formed in the users' minds (Lynch, 1960; Sternberg, 2000; Southworth, 1989; Bentley et al., 1985). Parameters such as architectural style, physical quality, quality of materials, spatial variety, presence and quality of fountain / sculpture, paving material quality, attractive building façade, transition features, well-defined spaces are also physical factors affecting the evaluation of the quality of the squares (Moulaert et al., 2013; Vandell \& Lane, 1989; White, 1999; Whyte, 1980; Ewing \& Handy, 2009).

- The parameters of squares surrounded by units with mixed functions (Southworth, 1989; Madanipour, 1999; Rowley, 1998; Jacobs, 1961; Bentley et al., 1985), the variety of activities (White, 1999; Carmona, 2014) the realization of various events and celebrations (Carr et al., 1992), the level of permeability (Rowley, 1998; Jacobs, 1961; Gehl, 2002; Bentley et al., 1985; Montgomery, 1998), fine grain (Jacobs, 1961; Rowley, 1998) lead to increased social interaction, the intensive use of the squares, and consequently the level of vitality of the squares.

- The level of accessibility with various transportation facilities from different points of the city is also one of the qualities of good squares (CABE and DETR, 2001; Lynch, 1981; Carmona et al., 2003; Project for Public Spaces [PPS], 2000). The presence of axles and connection points (linkages) have a positive effect in terms of the vitality, while the traffic and high noise levels lead to an overall drop in comfort (Smith et al., 1997; Gehl, 2002, 2006; Appleyard \& Lintell, 1972; Department of the Environment [DoE], 1994). Movement patterns of pedestrians, activity, mobility, outdoor activity, level of crowding, traffic of people, opening hours, presence of people attractors, richness are the secondary concepts under the pedestrian activity which should be quantified (Commission for Architecture and the Built Environment [CABE], 2007; PPS, 2000; Montgomery, 1998; Smith et al., 1997).

- The presence of historical buildings or heritage sites are affecting the quality of the squares and play an important role in transforming social memory (Schulz, 1971; DoE, 1994; Southworth, 1989; Gehl architects, 2002). Urban squares form an integral part of public life by creating a point of attraction in the urban space with their monumental structures, elements, functional features, activities. The squares also designate the image and identity of the cities (Banerjee \& Southworth, 1991; Lynch, 1960, 1981).

- Squares are public spaces that are focused on human needs and body-scale standards. Comfort is therefore an important quality component. Human scale (Ewing \& Handy, 2009;) inclusiveness (Commission for Architecture and the Built Environment, 2001; Madanipour, 2006, 2010; Khan et al., 2014), active and passive engagement / involvement (Carr et al., 1992; Carmona, 2019; Carmona \& Matos Wunderlich, 2012), suitability for children / playfulness, personalization, movable and individual or group sitting area, walk, stand, stay opportunities, sub-space, lighting units, public art can be evaluated as components of comfort (Appleyard, 1981; Sternberg, 2000; Bentley et al., 1985). 
- Maintaining economic vitality, opening to various users of the society, cleanliness and management, common rules and the services squares offer are also taken into consideration in the quality assessment of the squares (Doi et al., 2008; Commission for Architecture and the Built Environment, 2001; Montgomery, 1998; Whyte, 1988; Panagopoulos et al., 2016).

\subsection{Space syntax parameters}

Within the scope of the study, in view of syntactic analysis, connectivity, global and local integration values, visibility and isovist space graphics are used in terms of discussing quality of the squares. Local integration (R3) gives the value of the axis lines three steps deep, while the global integration $(\mathrm{Rn})$ calculates the depth value according to the whole system. The R3 value refers to pedestrian mobility, the spatial experience and encounters of local users, while the $\mathrm{Rn}$ value refers to pedestrian and vehicle traffic, the movement of visitors and local users together. Connectivity value "is the number of other lines with which an axial line intersects" (Hillier \& Hanson, 1984, p. 103). The high connectivity value means that the accessibility value of the axles is high.

Isovist space created by the spatial configuration affects the spatial experience and the readability of the spaces (Hillier, 1984). Visibility Graph Analysis (VGA) developed by Turner et al. (2001) provides data on visual experience. VGA map refers to areas where urban attraction and visibility are high. Many studies that are imple- mented SSX in urban outdoor areas reveal that integrated spaces are used extensively by people. Visual and spatial integration of urban space has a strong relationship with human movements (Mahmoud \& Omar, 2015; Desyllas \& Duxbury, 2001; Hillier et al., 1993; Parvin et al., 2007; Valipour et al., 2019). Moreover, stemmed from the studies, it has been accepted that there is a strong relationship between movement density and spatial integration (Hillier, 1996; Read, 1999).

\section{Findings of the study}

\subsection{Findings based on public space quality parameters}

\subsubsection{Location / Form / Visual and physical qualities}

BS is located central location of İstanbul. The square is surrounded by many educational institutions, commercial units, religious and cultural buildings, and its waterfront part is Barbaros Park (BP). This is a transition area and is also an activity area for skating. BS is directly related to Beşiktaş Street and Barbaros Boulevard (BB) which are major avenues in İstanbul. The SMS, surrounded by channels, is surrounded by high monumental buildings and only these buildings are perceived from the sea only as a silhouette. The square is only accessible on foot and by sea.

San Marco is more imageable than Beşiktaş because of having landmark structure such as campanile, basilica. A well-legible and good environmental image provides a good spatial experience while maintaining a sense of

Table 1. Location / Form / Visual and physical quality parameters

\begin{tabular}{|c|c|c|c|c|c|}
\hline \multirow{2}{*}{$\begin{array}{l}\text { ASPECTS } \\
\text { OF URBAN } \\
\text { SQUARE }\end{array}$} & \multirow{2}{*}{\multicolumn{2}{|c|}{ VARIABLES }} & \multirow{2}{*}{ REFERENCE } & \multicolumn{2}{|c|}{ SCORE } \\
\hline & & & & SAN MARCO & BEŞİKTAŞ \\
\hline \multirow{11}{*}{$\begin{array}{l}\text { Location / Form } \\
\text { / Visual and } \\
\text { physical quali- } \\
\text { ties }\end{array}$} & 1 & central location & $\begin{array}{l}\text { Sitte, 1965/1889; Bacon, 1974; Sternberg, 2000; } \\
\text { Zucker, 1970; Southworth, 1989; Madanipour, } \\
\text { 1999; Brown, 1985; Montgomery, } 1998\end{array}$ & 4 & 4 \\
\hline & 2 & transportation facilities & Gehl architects, 2002 & 4 & 5 \\
\hline & 3 & form & $\begin{array}{l}\text { Hajmirsadeghi et al., 2012; Carmona et al., 2003; } \\
\text { Krier, } 1979\end{array}$ & 4 & 2 \\
\hline & 4 & size & $\begin{array}{l}\text { Hajmirsadeghi et al., 2012; Lynch, 1971; Alexan- } \\
\text { der et al., 1977; Whyte, 1988 }\end{array}$ & 3 & 3 \\
\hline & 5 & legibility & $\begin{array}{l}\text { Lynch, 1960; Ewing \& Handy, 2009; Sternberg, } \\
\text { 2000; Erem and Şener, 2008; Southworth, 1989; } \\
\text { Bentley et al., 1985; Montgomery, 1998; }\end{array}$ & 4 & 3 \\
\hline & 6 & imagiblity & $\begin{array}{l}\text { Ewing and Handy, 2009; Lynch, 1960; Montgom- } \\
\text { ery, } 1998\end{array}$ & 5 & 3 \\
\hline & 7 & visual experience & $\begin{array}{l}\text { Cullen, 1961; White, 1999; Sitte, 1965/1889; } \\
\text { Bentley et al., } 1985\end{array}$ & 4 & 4 \\
\hline & 8 & architectural quality & $\begin{array}{l}\text { Montgomery, 1998; Moulaert et al., 2013; Vandell } \\
\text { and Lane, 1989; Danisworo, 1989; Carr et al., } \\
\text { 1992; DoE, 1994 }\end{array}$ & 5 & 4 \\
\hline & 9 & fountain/sculpture & Whyte, 1980; Carr et al., 1992 & 4 & 4 \\
\hline & 10 & paving material quality & White, 1999; Carmona et al., 2003 & 5 & 3 \\
\hline & 11 & attractive building façade & Nasar, 2011; Gehl, 2002; Avila, 2001 & 5 & 3 \\
\hline & & & TOTAL SCORE & 47 & 38 \\
\hline
\end{tabular}


security (Lynch, 1960). BS is easily detected from many different points from the sea and land, as Lynch mentions and can be detected from across the Bosphorus. However, the lack of clear boundaries that define the square weakens readability. SMS campanile is perceived from the city and sea easily, but the square itself is not visible (Table 1).

\subsubsection{Vitality / Pedestrian activity}

Museums, libraries, basilicas, trade units and religious buildings especially define SMS. It is bordered by commercial buildings with restaurants and cafes on the ground floor. Buildings are permeable on the street level, therefore pedestrian traffic flows easily. There is no vehicle traffic in and around SMS. SMS is one of the most powerful touristic attractions of Venice, where people perform optional activities such as experience, stopping and watching tourists stop, watch and enjoy the historic buildings and atmosphere. Both squares are pedestrian-oriented, but SMS is surrounded by channels which makes it difficult to be accessed by elderly and disabled individuals due to the steep stairs at bridges.BS is a throbbing transportation and transfer center where city users carry out their necessary activities such as waiting for buses, going to school, going to work and with people are always on the move for going to work or school.
Inhabitants and tourists can move freely in both BS and SMS, whereas some activities such as cycling are restricted in at monumental square, SMS inhabitants and tourists can move freely in BS. Except for museums and educational institutions, the cafe and commercial units are open till late with intense vehicle and human traffic observed at all times in BS. The opening hours of buildings, mostly historic buildings and museums are restricted for certain periods in SMS. BS serves both tourists and locals at all time throughout the year whereas SMS serves mainly tourists. SMS is rather empty during winter due to lack of tourists and at times high water levels (Table 2).

\subsubsection{Identity / Image / Sense of place}

Museums, religious buildings, commercial structures and the ground floor cafes allow people to interact, facilitate group activities, and to socialize in SMS. SMS offers a suitable environment for collective events in the city. BS, on the other hand, is mostly used as a transition area by pedestrians, and the benches and urban stairs in the square enable collective interaction. The cafes located in the eastern part of the square facilitates interaction for people visiting the square. Part of the square is used by skaters. SMS are buildings such as the San Marco Basilica, Duke's Palace, and campanile, which are the symbol of the city and are important for the city's identity (Table 3 ).

Table 2. Vitality / Pedestrian activity quality parameters

\begin{tabular}{|c|c|c|c|c|c|}
\hline \multirow{2}{*}{$\begin{array}{l}\text { ASPECTS } \\
\text { OF URBAN } \\
\text { SQUARE }\end{array}$} & \multirow{2}{*}{\multicolumn{2}{|c|}{ VARIABLES }} & \multirow[b]{2}{*}{ REFERENCE } & \multicolumn{2}{|c|}{ SCORE } \\
\hline & & & & $\begin{array}{c}\text { SAN } \\
\text { MARCO }\end{array}$ & BEŞİTAŞ \\
\hline \multirow{12}{*}{$\begin{array}{l}\text { Vitality / } \\
\text { Pedestrian } \\
\text { activity }\end{array}$} & 12 & mixed land use & $\begin{array}{l}\text { Southworth, 1989; Madanipour, 1999; Rowley, 1998; } \\
\text { Jacobs, 1961; Bentley et al., 1985; Montgomery, } 1998\end{array}$ & 5 & 5 \\
\hline & 13 & activity variety & $\begin{array}{l}\text { White, 1999; Gehl, 1971/1987; Gehl architects, 2002; } \\
\text { Srinaga et al., 2018; Hajmirsadeghi et al., 2012; } \\
\text { Carmona, 2014; Rivlin, 1994; CABE and DETR, } 2001\end{array}$ & 3 & 5 \\
\hline & 14 & permability & $\begin{array}{l}\text { Rowley, 1998; Jacobs, 1961; Gehl, 2006; Bentley et al., } \\
\text { 1985; Montgomery, } 1998\end{array}$ & 4 & 5 \\
\hline & 15 & $\begin{array}{l}\text { ceremony, celebra- } \\
\text { tion, festivity }\end{array}$ & Carr et al., 1992 & 5 & 5 \\
\hline & 16 & fine grain & Jacobs, 1961; Rowley, 1998 & 4 & 3 \\
\hline & 17 & services & Oldenburg, 1989 & 4 & 4 \\
\hline & 18 & accesibility & $\begin{array}{l}\text { Doi et al., 2008; CABE and DETR, 2001; Southworth, } \\
\text { 1989; Madanipour, 1999; Lynch, 1981; Carmona et al., } \\
\text { 2003; Carmona and Matos Wunderlich, 2012; Gehl ar- } \\
\text { chitects, 2002; Hajmirsadeghi et al., 2012; Moulaert et al., } \\
\text { 2013; Roger Tym \& Partners, 2006; PPS, 2000; Srinaga } \\
\text { et al., } 2018\end{array}$ & 4 & 5 \\
\hline & 19 & linkages & $\begin{array}{l}\text { Srinaga et al., 2018; PPS, 2000; Gehl, 2002; CABE and } \\
\text { DETR, 2001; Roger Tym \& Partners, } 2006\end{array}$ & 4 & 5 \\
\hline & 20 & car traffic & DoE, 1994; Oktay et al., 2009 & 5 & 1 \\
\hline & 21 & level of crowding & Oktay et al., 2009 & 5 & 5 \\
\hline & 22 & $\begin{array}{l}\text { presence of people } \\
\text { attractors }\end{array}$ & $\begin{array}{l}\text { Montgomery, 1998; Danisworo, 1989; Whyte, 1985; PPS, } \\
2000\end{array}$ & 5 & 3 \\
\hline & 23 & $\begin{array}{l}\text { variety in opening } \\
\text { hours }\end{array}$ & Montgomery, 1998 & 3 & 5 \\
\hline & & & TOTAL SCORE & 51 & 51 \\
\hline
\end{tabular}


Table 3. Identity / Image / Sense of place quality parameters

\begin{tabular}{|l|l|l|l|c|c|}
\hline $\begin{array}{c}\text { ASPECTS } \\
\text { OF URBAN } \\
\text { SQUARE }\end{array}$ & \multicolumn{2}{|c|}{ VARIABLES } & \multicolumn{2}{c|}{ REFERENCE } & SCORE \\
\cline { 3 - 6 } $\begin{array}{l}\text { Identitiy / Image } \\
\text { / Sense of place }\end{array}$ & 24 & meaningfullness & $\begin{array}{l}\text { Lennard, 1987; Carmona, 2019; Carmona and Matos } \\
\text { Wunderlich, 2012 }\end{array}$ & 5 & 3 \\
\cline { 2 - 6 } & 25 & historical value & Gehl architects, 2002; Southworth, 1989 & 5 & 3 \\
\cline { 2 - 6 } & 26 & landmark & Lynch, 1960; Montgomery, 1998 & 5 & 3 \\
\cline { 2 - 6 } & 27 & sense of place & $\begin{array}{l}\text { Relph, 1976; Banerjee \& Southworth, 1991; Sternberg, } \\
\text { 2000; Schul, 1971; Southworth, 1989; Lynch, 1981; } \\
\text { Carmona et al., 2003; Roger Tym \& Partners, 2006 }\end{array}$ & 20 \\
\hline
\end{tabular}

\subsubsection{Comfort}

SMS is facing natural disasters such as flooding at certain times of the year. Landscaping elements are not available in SMS and lighting units are located on the building facades. Security members and police supervise the square. In BS, Natural elements located in the garden of the mausoleum and the boundaries of the square contribute to the feeling of closure in BS. In BS, the lighting elements provide sufficient illumination and help do not pose eliminate safety issues hazard for night-time use.
While semi-open space use in SMS significantly improves space comfort, BS does not have many semi-open spaces. In SMS buildings are greater than human scale, whereas in BS buildings are closer to the human scale. The advantage of SMS is that it is reserved for sub-squares with a high enclosure effect, which allows for different activities and uses. The sub-areas of BS include sitting areas around the Eagle Square and in the cafes within the transfer station, while all other sub-square components are used as a transition areas (Table 4).

Table 4. Comfort quality parameters

\begin{tabular}{|c|c|c|c|c|c|}
\hline \multirow{2}{*}{$\begin{array}{l}\text { ASPECTS } \\
\text { OF } \\
\text { URBAN } \\
\text { SQUARE }\end{array}$} & \multirow{2}{*}{\multicolumn{2}{|c|}{ VARIABLES }} & \multirow{2}{*}{ REFERENCE } & \multicolumn{2}{|c|}{ SCORE } \\
\hline & & & & SAN MARCO & BEŞİKTAŞ \\
\hline \multirow[t]{16}{*}{ Comfort } & 28 & human scale & $\begin{array}{l}\text { Ewing \& Handy, 2009; Lennard, 1987; Katz et al., 1994; } \\
\text { Ashihara, 1981; Shirvani, 1985; Moulaert et al., 2013; } \\
\text { Montgomery, 1998; Vandell and Lane, } 1989\end{array}$ & 2 & 5 \\
\hline & 29 & safe and security & $\begin{array}{l}\text { Sternberg, 2000; Lynch, 1981; Doi et al., 2008; Jarvis, 1993; } \\
\text { Johnson, 1988; Lennard, 1987; Appleyard, 1981; Carmona } \\
\text { et al., 2003; Danisworo, 1989; Southworth, 1989; Srinaga } \\
\text { et al., 2018; Hajmirsadeghi et al., } 2012\end{array}$ & 4 & 4 \\
\hline & 30 & inclusiveness & Carmona et al., 2003; Madanipour, 2006; 2010; Khan et al., 2014 & 3 & 4 \\
\hline & 31 & $\begin{array}{l}\text { active and passive } \\
\text { engagement }\end{array}$ & $\begin{array}{l}\text { Carr et al., 1992; Carmona, 2019; Carmona and Matos } \\
\text { Wunderlich, } 2012\end{array}$ & 4 & 3 \\
\hline & 32 & suitable for children & Appleyard, 1981; Carr et al., 1992; Sternberg, 2000 & 3 & 4 \\
\hline & 33 & personalization & Bentley et al., 1985 & 2 & 2 \\
\hline & 34 & movable sitting area & Carr et al., 1992; Whyte, 1980, 1988; Carmona, 2014 & 1 & 1 \\
\hline & 35 & $\begin{array}{l}\text { stay, walk and stand } \\
\text { opportunities }\end{array}$ & Gehl architects, 2002 & 2 & 3 \\
\hline & 36 & sub-spaces & Hajmirsadeghi et al., 2012 & 4 & 3 \\
\hline & 37 & lighting units & Hajmirsadeghi et al., 2012 & 5 & 5 \\
\hline & 38 & natural elements & $\begin{array}{l}\text { Panagopoulos et al., 2016; Chiesura, 2004; Lennard, 1987; } \\
\text { Kaplan and Kaplan, 1989; Carr et al., 1992; Gehl, 2002; Avila, } \\
\text { 2001; Carr et al., 1992; Banerjee, 2001; Smith et al., } 1997\end{array}$ & 3 & 4 \\
\hline & 39 & sun, wind, climate & Whyte, 1988; Brown, 1985; Gehl architects, 2002 & 4 & 4 \\
\hline & 40 & seasonal strategy & PPS, 2000 & 4 & 1 \\
\hline & 41 & sustainable energy use & Carmona et al., 2003; Srinaga et al., 2018 & 1 & 1 \\
\hline & 42 & public art & Carr et al., 1992; Whyte, 1988; Carmona et al., 2003 & 1 & 2 \\
\hline & 43 & shelter & Hajmirsadeghi et al., 2012 & 1 & 1 \\
\hline & & & TOTAL SCORE & 44 & 47 \\
\hline
\end{tabular}




\subsubsection{Integrative / Responsiveness}

SMS is a monumental square used for many different events. The functions and architectural qualities of the historic buildings surrounding the square determine the purpose of the square. As a tourist attraction, SMS is a square for major events, celebrations and tourist activities.

ARDM (Ataturk Republic Democracy Monument) and its surroundings hold a number of events, such as exhibitions, events and so on. The coastal area is used for strolling, sea view watching, relaxing and monuments are used for meeting and waiting. BS used extensively by tourists, students, young people, adults, elderly people because educational facilities and museums located around it and it offers great sea panorama. BS used extensively by tourists, students, young people, adults, elderly people as a result of the educational facilities and museums located around it. It offers great exceptional views to the sea and the cityscape panorama. BS is focused on the local user mostly, while SMS is a pier square that serves tourists more (Table 5).

\subsubsection{Managerial}

SMS, which is the center of the political and religious events of the period, is a frequent destination for many tourists.
There is no element that will cause hygiene problems and cause visual pollution. Tourist-oriented and expensive restaurants and souvenir shops are located around the square.

BS cleaning is carried out by the municipality through vehicles that can be controlled from satellite momentarily, the cleaning services prove mostly effective as there are no visible trash-related or hygienic problems spotted at the square. There are low-price shops and food kiosks for the local people, especially university students (Table 6).

\subsection{Findings on space syntax analysis of squares}

Within the scope of the study, connectivity, local and global integration values, visibility analysis (VGA) of the squares and their surroundings are measured and isovist graphics are produced (Table 7).

The high connectivity on the western axis surrounding the ARDM means that this route has many different connections and its accessibility is high. Connectivity values of transition routes in $\mathrm{BP}$, which provide access to the pier, are also high. (Figure $3 \mathrm{a}$ ). The average connectivity value of Venice is 2,41578; the highest value was measured as 11 . SMS is high in connection with the northern part of Venice and low in connection with the coast. The connectivity

Table 5. Integrative / Responsiveness quality parameters

\begin{tabular}{|c|c|c|c|c|c|}
\hline \multirow{2}{*}{$\begin{array}{c}\text { ASPECTS } \\
\text { OF URBAN } \\
\text { SQUARE }\end{array}$} & \multirow{2}{*}{\multicolumn{2}{|c|}{ VARIABLES }} & \multirow{2}{*}{ REFERENCE } & \multicolumn{2}{|c|}{ SCORE } \\
\hline & & & & SAN MARCO & BEŞİKTAŞ \\
\hline \multirow{4}{*}{$\begin{array}{l}\text { Integrative / } \\
\text { Responsiveness }\end{array}$} & 44 & democratic & Carr et al., 1992 & 4 & 4 \\
\hline & 45 & responsiveness & Bentley et al., 1985; Vandell and Lane, 1989; Banerjee, 2001 & 3 & 4 \\
\hline & 46 & adaptability & $\begin{array}{l}\text { Southworth, 1989; Montgomery, 1998; Carmona, 2019; } \\
\text { Bentley et al., } 1985\end{array}$ & 3 & 4 \\
\hline & 47 & user diversity & Carmona, 2019; Moulaert et al., 2013 & 5 & 5 \\
\hline & & & TOTAL SCORE & 15 & 17 \\
\hline
\end{tabular}

Table 6. Managerial quality parameters

\begin{tabular}{|c|c|c|c|c|c|}
\hline \multirow{2}{*}{$\begin{array}{c}\text { ASPECTS } \\
\text { OF } \\
\text { URBAN } \\
\text { SQUARE }\end{array}$} & \multirow{2}{*}{\multicolumn{2}{|c|}{ VARIABLES }} & \multirow{2}{*}{ REFERENCE } & \multicolumn{2}{|c|}{ SCORE } \\
\hline & & & & SAN MARCO & BEŞİKTAŞ \\
\hline \multirow[t]{3}{*}{ Managerial } & 48 & care and cleaning & $\begin{array}{l}\text { White, 1999; CABE, 2007; Southworth, } \\
\text { 1989; Appleyard, } 1981\end{array}$ & 5 & 4 \\
\hline & 49 & provide food and baverage services & Whyte, 1988 & 4 & 5 \\
\hline & 50 & regulations & Srinaga et al., 2018 & 5 & 3 \\
\hline & & & TOTAL SCORE & 14 & 12 \\
\hline
\end{tabular}

Table 7. Space syntax values of İstanbul and Venice

\begin{tabular}{|l|c|c|c|c|c|c|}
\hline & \multicolumn{2}{|c|}{ Minimum } & \multicolumn{2}{c|}{ Average } & \multicolumn{3}{c|}{ Maksimum } \\
\hline & Venedik & Beşiktaş & Venedik & Beşiktaş & Venedik & Beşiktaş \\
\hline Connectivity & 0 & 0 & 2,41578 & 2,89337 & 11 & 13 \\
\hline Global integration & 0,133927 & 0,3539048 & 0,272234 & 0,756599 & 2,29857 & 1,265562 \\
\hline Local integration & 0,210897 & 0,3333333 & 1,21662 & 1,42329 & 2,70267 & 2,88112 \\
\hline
\end{tabular}


values of the axes in the square were measured as $2,3,4$, 6 (Figure 4a).

The highest global integration value of Beşiktaş city fabric was measured as 1,265562 . The global integration value $(1,26562)$ of Beşiktaş Avenue has been measured higher than Çırağan Street $(0,75784)$ and BB $(1,16493)$ (Figure 3b). The average global integration value of Venice is 0,272234 ; the highest global integration value is measured as 2,29857. Land connection is restricted due to topographical features of Venice separated by canals. Accessibility opportunities of the island are limited and connection to mainland is limited to trains and busses. It can be said that the square has high accessibility value compared to whole city, but does not tend to integrate (Figure $4 \mathrm{~b}$ ).

The high local integration analysis values of $\mathrm{BB}$ and Beşiktaş Avenue surrounding BS indicate that these routes are used extensively by pedestrians. The high integration in the part of Beşiktaş Street separating BP and BP is con- firmed by observational data. (Figure 3c). In SMS, local integration values are high in areas with commercial functions located in the northern part of the square. SMS is used extensively for social interactions and meetings, and the pedestrian flow is high (Figure 4c). Visual integration of SMS is high at the main square, the transition point to the sub-square and the northern part of the square. These areas represent areas with high urban attraction and where the square is perceived mostly. BB and BP, have high integration values. BS provides the transition between the coastal and busy urban areas and is preferred as a high attraction point (Figure 5).

360-degree visible areas of the squares were analyzed with isovist graphics. BS is more perceptible and visible in the urban context than SMS. BS, where the coast and land relations are stronger than San Marco, has the opportunity to be perceived from an area that is approximately four times larger than SMS (Figure 6).

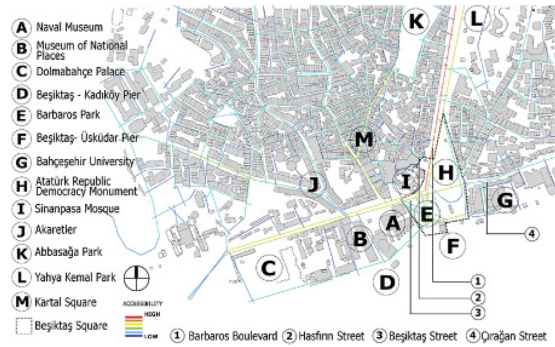

a) Connectivity analysis

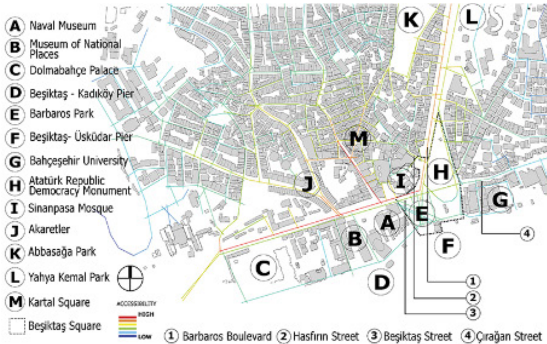

b) Global integration analysis

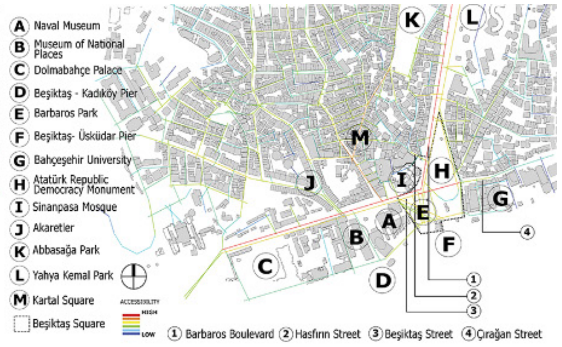

c) Local integration analysis

Figure 3. Connectivity, global and local integration analysis of Beşiktaş Square

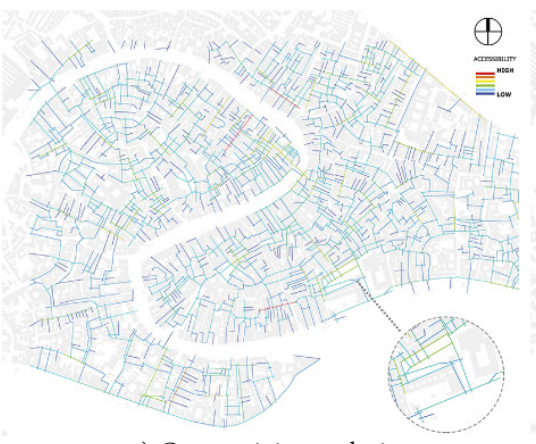

a) Connectivity analysis

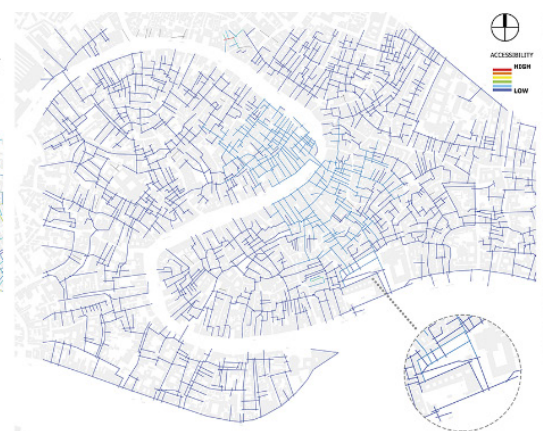

b) Global integration analysis

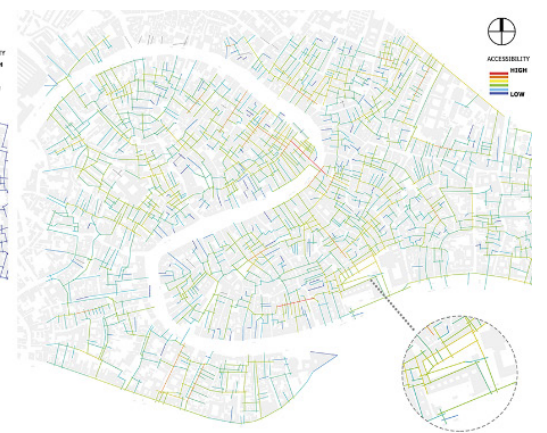

c) Local integration analysis

Figure 4. Connectivity, global and local integration analysis of Venice and San Marco Square

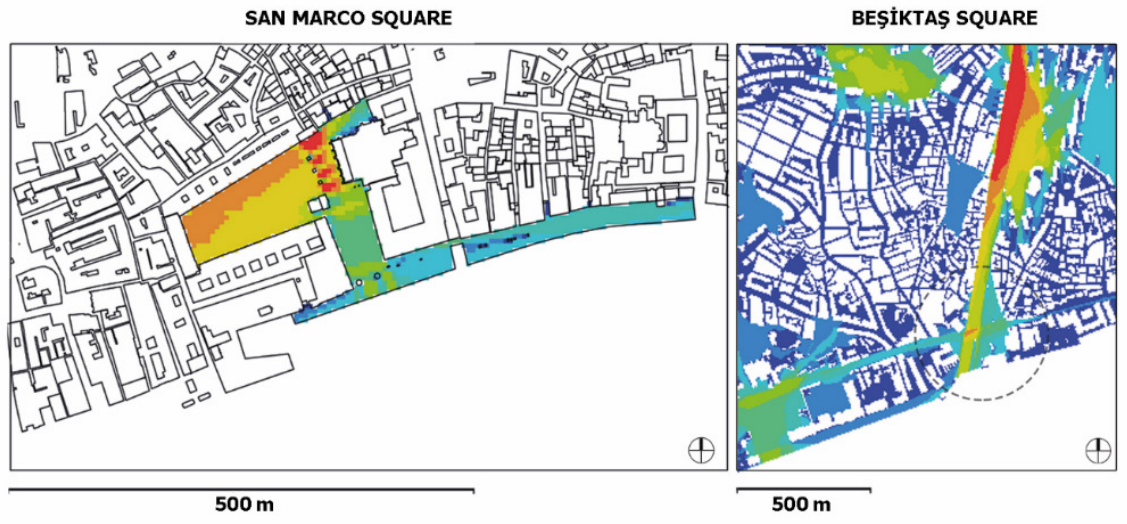

Figure 5. Visibility graph analysis (VGA) of squares 


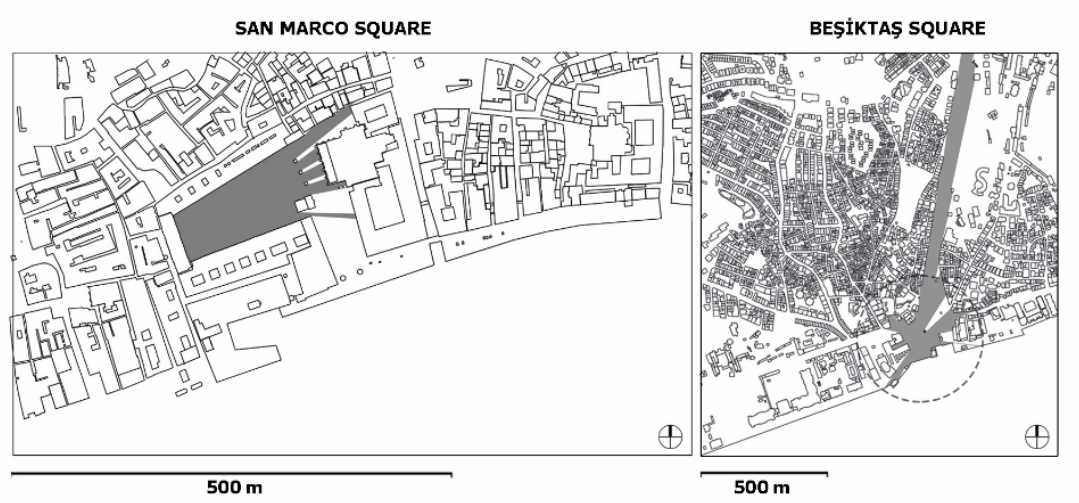

Figure 6. Isovist polygon of squares

\section{Results and discussion}

In the observational evaluation, BS was measured at high value in the comfort and integrative parameters. This is because it is close to the human scale, it is related to natural elements, it is for children, it is for different ages and groups of people in society, it has sub-areas for many different activities, such as sitting, walking, playing, watching. BS can be transformed into a living part of the city, adapting to changing social, political and spatial conditions. The monumental and symbolic value of SMS is dominant, so it is not affected by changing social and daily conditions. The field of view is more restricted, but it's surrounded by buildings of a much different scale than the overall city context. The campanile and basilica increase readability and imageability of SMS.

According to local integration analysis of BS, intersection of streets are high values so, vehicle and pedestrian traffic are busy in these areas. The global integration values of the urban fabric of Venice are low. The integration values of SMS are below average. This shows that the city's symbolic meaning and architecture quality of SMS are the reason for its very busy use, although it is not more integrated than other parts of the city (Figure $7 \mathrm{a}$ ).

There is a high social interaction and a high pedestrian flow are observed in BS according to local integra- tion value. Moreover, BS offers a high visual experience in urban fabric. SMS is isolated from urban fabric with its surrounding high buildings and limited passing points. According to SSX, the areas with high integration value are in front of the basilica and on the north front of the square. This means that the room effect of the square in urban fabric is strong. According to Isovist space analysis, Beşiktaş district is clearly visible along $\mathrm{BB}$, which means it is highly readable. SMS has an isolated area and it is only recognized through the monumental buildings and campanile surrounding it. It is not located on the main traffic axles (Figure 7b).

The maximum values of connectivity, global and local integration in BS, consisting of five different sub-squares, were measured higher than SMS, based on the values obtained in the SSX. High values indicate a high sense of confidence, with the confidence of BS being approachable, accessible, enabling social interaction and, high pedestrian mobility, high visibility and imageability. However, the observational analysis showed that the monumental SMS performs better in terms of location, identity, managerial quality parameters than BS. This has shown that monumental at squares, an attraction can be of high spatial quality, even if they are disconnected from the city's daily life and the urban fabric. The spatial quality of SMS has been determined by architectural quality, historical and

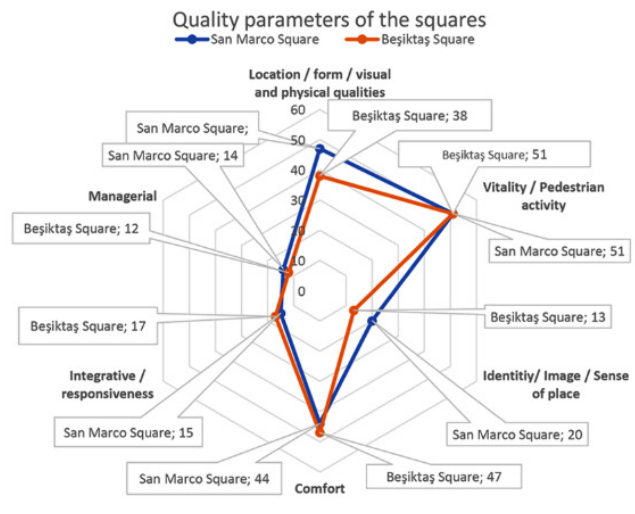

a)

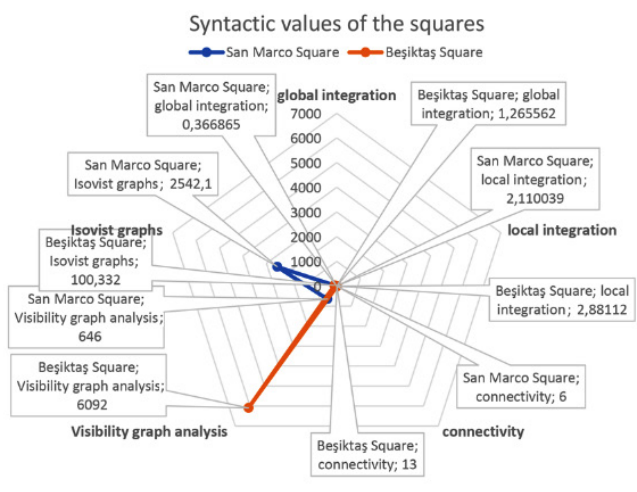

b)

Figure 7. Radar diagram showing quality assessment of the squares according to observation and syntactic measures 
cultural memory, the concentration of monumental buildings, independent from the spatial configuration of city. However, the spatial configuration of BS and urban fabric verified the spatial quality of $B S$ and provided accurate information about quality parameters. BS's high syntactic values have shown that the square is a key transit point those visitors, tourists and townspeople use frequently.

\section{Conclusions}

The squares, the destination of townspeople, visitors, and tourists, are an integral part of the city's symbol and identity. So, creating better quality, sustainable, vibrant, comfortable, integrated squares is a critical research topic of architecture and urban planning. In line with the aforementioned, this study emphasized that urban space quality also depends on different experiential and urban scale parameters such as social life, physical quality, location, urban or place identity, spatial comfort, inclusive design principles, and managerial vision in addition to spatial configuration. Instead of examining urban spaces as isolated and separate urban parts, establishing connections between different scales and developing interdisciplinary approaches will be decisive in creating quality urban spaces.

\section{Future studies}

This study showed that SSX is an efficient tool for measuring the quality of squares, providing accurate data for quality of space, but should be supported with observational data. It is estimated that the three-dimensional SSX, rather than two dimensions, can provide more accurate information in the quality measurement. But beyond that, abstract concepts of detailed information, identity and meaning of architectural elements in the built environment should be added as an input to the SSX measurements. The SSX has the potential to provide an important information area in the quality measurement of squares. Because the parameters and variables used to measure the quality of squares are very diverse and the quality of the space itself is a highly sophisticated and complex concept. The development of mixed methods in examining the concept of quality in urban spaces will provide a better understanding of the effect of spatial morphology on the built environment.

\section{References}

Abshirini, E., \& Koch, D. (2017). Resilience, space syntax and spatial interfaces: The case of river cities. A/Z ITU Journal of the Faculty of Architecture, 14(1), 25-41.

https://doi.org/10.5505/itujfa.2017.65265

Agboola, O. P., Rasidi, M. H., Said, I. B., Zakka, S. D., \& Shuaibu, A.-W. (2018). Residents' social interactions in market square and its impact on community well-being. Journal of Contemporary Urban Affairs, 2(2), 24-32.

https://doi.org/10.25034/ijcua.2018.3668

Agirbas, A., \& Ardaman, E. (2015). A morphological comparison of urban tissues of Trani and Galata. Journal of Architecture and Urbanism, 39(4), 232-247.

https://doi.org/10.3846/20297955.2015.1113899
Albrechts, L., Schreurs, J., \& Van den Broeck, J. (2003). In search indicators and processes for strengthening spatial quality: The case of Belgium. Built Environment, 29(4), 288-295.

https://doi.org/10.2148/benv.29.4.288.54294

Alexander, C., Ishikawa, S., Silverstein, M., Jacobson, M., Fiksdahl-King, I., \& Shlomo, A. (1977). A pattern language: Towns, buildings, construction. Oxford University Press.

Appleyard, D., \& Lintell, M. (1972). The environmental quality of city streets: The residents' viewpoint. Journal of the American Planning Association, 38(2), 84-101. https://doi.org/10.1080/01944367208977410

Appleyard, D. (1981). Livable streets. University of California Press.

Arruda Campos, M. B. M. D. (1997). Strategic space: Patterns of use in public squares of the city of London. In M. D. Major, L. Amorim, \& F. Dufaux (Eds.), Space Syntax - First International Symposium Proceedings (Vol. 2, pp. 26.01-26.11), Space Syntax Laboratory, University College London.

Arruda Campos, M. B. M. D. (2000). Urban public spaces: a study of the relation between spatial configuration and use patterns [PhD thesis]. University College London, United Kingdom.

Ashihara, Y. (1981). Exterior design in architecture. Van Nostrand Reinhold.

Avila, M. I. M. (2001). Factors that influence the social life and vitality of public spaces in Maracaibo - Venezuela. Case study: Plaza de la Madre and Plaza de la Republica. Virginia Polytechnic Institute and State University.

Bacon, E. (1974). Design of cities. Viking.

Banerjee, T., \& Southworth, M. (Eds.). (1991). City sense and city design: Writings and projects of Kevin Lynch. The MIT Press.

Banerjee, T. (2001). The future of public space: Beyond invented streets and reinvented places. Journal of the American Planning Association, 67(1), 9-24.

https://doi.org/10.1080/01944360108976352

Baytin, Ç. P. (2006). Public areas: The arenas of expression of identity. Mimarist Dosya: Kamusal Alan, 4, 78-81.

Bendjedidi, S., Bada, Y., \& Meziani, R. (2018). Open spaces: Spatial configuration, visibility analysis and use: Case study of mass housing in Biskra, Algeria. International Review for Spatial Planning and Sustainable Development, 6(4), 93-109. https://doi.org/10.14246/irspsd.6.4_93

Bendjedidi, S., Bada, Y., \& Meziani, R. (2019). Urban plaza design process using space syntax analysis: El-Houria plaza, Biskra, Algeria. International Review for Spatial Planning and Sustainable Development, 7, 125-142.

https://doi.org/10.14246/irspsda.7.2_125

Bentley, I., Alcock, A., Murrain, P., McGlynn, S., \& Smith, G. (1985). Responsive environment: A manual for designers (pp. 85-95). Architectural Press.

Brand, N., Kersten, I., Pot, R., \& Warmerdam, M. (2014). Research by design on the Dutch coastline: Bridging flood control and spatial quality. Built Environment, 40(2), 265-280. https://doi.org/10.2148/benv.40.2.265

CABE and DETR. (2001). The value of urban design. Thomas Telford.

Carmona, M. (2014). The place-shaping continuum: A theory of urban design process. Journal of Urban Design, 19(1), 2-36. https://doi.org/10.1080/13574809.2013.854695

Carmona, M. (2019). Principles for public space design, planning to do better. Urban Design International, 24, 47-59. https://doi.org/10.1057/s41289-018-0070-3

Carmona, M., \& Matos Wunderlich, F. (2012). Capital spaces: The multiple complex public spaces of a global city. Routledge. https://doi.org/10.4324/9780203118856 
Carmona, M., Heath, T., Oc, T., \& Tiesdell, S. (2003). Urban spaces-public places: The dimensions of urban design. Architectural Press.

Carr, S., Francis, M., Rivlin, L., \& Stone, A. M. (1992). Public space. Cambridge University Press.

Çil, E. (2006). Theoretical and methodological discussion of the space syntax analysis as a tool for reading the city. Megaron, 1(4), 218-233.

Collins, G. R., Collins, C. C., Collins, G. R., \& Sitte, C. (1986). Camillo Sitte: The birth of modern city planning. Rizzoli.

Commission for Architecture and the Built Environment. (2001). The value of urban design: A research project commissioned by $C A B E$ and DETR to examine the value added by good urban design. Thomas Telford.

Commission for Architecture and the Built Environment. (2006). The principles of inclusive design (They include you). https:// www.designcouncil.org.uk/sites/default/files/asset/document/ the-principles-of-inclusive-design.pdf

Cullen, G. (1961). The concise townscape. Routledge/Architectural Press.

Danisworo, M. (1989). Konsep peremajaan kota. Institut Teknologi Bandung.

Das, D. (2008). Urban quality of life: A case study of Guwahati. Social Indicators Research, 88, 297-310.

https://doi.org/10.1007/s11205-007-9191-6

Department of the Environment. (1994). Vitaland viable town centres: Meeting the challenge. HMSO.

Desyllas, J., \& Duxbury, E. (2001). Axial maps and visibility graph analysis: A comparison of their methodology and use in models of urban pedestrian movement. In Proceedings 3rd International Space Syntax Symposium (pp. 27.1-27.13), Atlanta.

Doi, K., Kii, M., \& Nakanishi, H. (2008). An integrated evaluation method of accessibility, quality of life, and social interaction. Environment and Planning B: Planning and Design, 35(6), 1098-1116. https://doi.org/10.1068/b3315t

Dutta, S., Bardhan, S., \& Bhaduri, S. (2013). Patterns of urbanization and environmental quality in the context of Indian cities. Environment and Urbanization Asia, 4(2), 287-299. https://doi.org/10.1177/0975425313510768

Erdönmez, M. E., \& Akı, A. (2005). Açık kamusal kent mekânlarının toplum ilişkilerindeki etkileri. YTU Arch. Fac. e-Journal, 1(1), 67-87.

Erem, Ö., \& Şener, E. G. (2008). Complexity versus sustainability in urban space: The case of Taksim Square, Istanbul. A|Z ITU Journal of the Faculty of Architecture, 5(1), 54-73.

Ewing, R., \& Handy, S. (2009). Measuring the unmeasurable: Urban design qualities related to walkability. Journal of Urban Design, 14(1), 65-84. https://doi.org/10.1080/13574800802451155

Fraser, A. (2020, June 04). Venice prepares to welcome back tourists. CGTN. https://newseu.cgtn.com/news/2020-06-04/Veniceprepares-to-welcome-back-tourists-R1Go8a0PII/index.html

Gehl architects. (2002). Public spaces and public life: City of Adelaide 2002. Adelaide City Council. http://www.adelaidecitycouncil.com/adccwr/publications/reports_plans/public_spaces_public_life.pdf

Gehl, J. (1987). Life between buildings: Using public space (J. Koch, Trans.). Van Nostrand Reinhold. (Original work published 1971)

Gehl, J. (2002). Public space and public life. City of Adelaide: 2002. https://observatorio.dadep.gov.co/sites/default/files/ documentos/li02_public-spaces.pdf

Gehl, J. (2010). Cities for people. Island Press.
Gehl, J., Kaefer, L. J., \& Reigstad, S. (2006). Close encounters with buildings. Urban Design International, 11, 29-47. https://doi.org/10.1057/palgrave.udi.9000162

Gökgür, P. (2006). Basic qualities of public area. Mimarist Dosya: Kamusal Alan, 4, 62-66.

Hajmirsadeghi, R. S., Shamsuddin, S., \& Foroughi, A. (2012). The impact of physical design factors on the effective use of public squares. International Journal of Fundamental Psychology and Social Sciences, 2(3), 49-56.

Hillier, B. (1996). Cities as movement economies. Urban Design International, 1, 41-60. https://doi.org/10.1057/udi.1996.5

Hillier, B., \& Hanson, J. (1984). The social logic of space. Cambridge University Press. https://doi.org/10.1017/CBO9780511597237

Hillier, B., Penn, A., Hanson, J., Grajewski, T., \& Xu, J. (1993). Natural movement: Or, configuration and attraction in urban pedestrian movement. Environment and Planning B: Planning and Design, 20(1), 29-66. https://doi.org/10.1068/b200029

Hu, H., Luo, Z., Chen, Y., Bian, Q., \& Tong, Z. (2017). Integration of space syntax into agent-based pedestrian simulation in urban open space. In CAADRIA 2017 - 22nd International Conference on Computer-Aided Architectural Design Research in Asia: Protocols (pp. 325-334), Flows and Glitches.

Jacobs, J. (1961). The death and life of great American cities. Penguin. Javadi, H. (2016). Sustainable urban public squares. European Journal of Sustainable Development, 5(3), 361-370. https://doi.org/10.14207/ejsd.2016.v5n3p361

Kaplan, R., \& Kaplan, S. (1989). The experience of nature: A psychological perspective. Cambridge University Press.

Katz, P., Scully, V., \& Bressi, T. W. (1994). The new urbanism: Toward an architecture of community. McGraw-Hill.

Khan, A. Z., Moulaert, F., Schreurs, J., \& Miciukiewicz, K. (2014). Integrative spatial quality: A relational epistemology of space and transdisciplinarity in urban design and planning. Journal of Urban Design, 19(4), 393-411.

https://doi.org/10.1080/13574809.2014.936142

Krier, R. (1979). Urban space. Rizzoli.

Lennard, S. H. C. (1987). Livable cities: People and places: Social and design principles for the future of the city. Gondolier Press.

Lu, Y., Gou, Z., Ye, Y., \& Sheng, Q. (2019). Three-dimensional visibility graph analysis and its application. Environment and Planning B: Urban Analytics and City Science, 46(5), 948-962. https://doi.org/10.1177/2399808317739893

Lynch, K. (1960). The image of the city. MIT Press.

Lynch, K. (1971). Site planning (2nd ed.). MIT Press.

Lynch, K. (1981). Good city form. MIT Press.

Madanipour, A. (1999). Why are the design and development of public spaces significant for cities? Environment and Planning B: Planning and Design, 26(6), 879-891. https://doi.org/10.1068/b260879

Madanipour, A. (2006). Roles and challenges of urban design. Journal of Urban Design, 11(2), 173-193. https://doi.org/10.1080/13574800600644035

Mahmoud, A. H., \& Omar, R. H. (2015). Planting design for urban parks: Space syntax as a landscape design assessment tool. Collection of Frontiers of Architectural Research, 4, 35-45. https://doi.org/10.1016/j.foar.2014.09.001

Major, M. D., Penn, A., Spiliopoulou, G., \& Spende, N. (1999, January). In with the Right Crowd: Crowd movement and space use in Trafalgar Square during the New Year's Eve celebrations. In Space Syntax 2nd International Symposium (pp. 1-17), Brazil.

Major, M., Penn, A., Spiliopoulou, G., Spende, N., Doxa, M., \& Fong, P. (2000). Following the crowd: Spatial layout and 
crowd behaviour. Architectural Research Quarterly, 4(3), 257264. https://doi.org/10.1017/S1359135500000282

Mazumdar, S. (2007). Kentsel yaşam kalitesi ve yer duygusu. Mimarlik Dergisi, 335, 32-36.

Mehta, V. (2014). Evaluating public space. Journal of Urban Design, 19(1), 53-88. https://doi.org/10.1080/13574809.2013.854698

Montgomery, J. (1998). Making a city: Urbanity, vitality and urban design. Journal of Urban Design, 3(1), 93-116. https://doi.org/10.1080/13574809808724418

Moulaert, F., Van Dyck, B., Khan, A. Z., \& Schreurs, J. (2013). Building a meta-framework to 'address' spatial quality. International Planning Studies, 18(3-4), 389-409. https://doi.org/10.1080/13563475.2013.837137

Nasution, A. D., \& Zahrah, W. (2012). Public open space privatization and quality of life, case study Merdeka Square Medan. Procedia - Social and Behavioral Sciences, 36, 466-475. https://doi.org/10.1016/j.sbspro.2012.03.051

Okan University. (2015, May 02). Evaluation of the future of sea transportation in Istanbul. ISTKA.

https://www.istka.org.tr/media/20863/\%C4\%B0stanbulda-deniz-ula\%C5\%9F\%C4\%B1 m\%C4\%B1n\%C4\%B1ngelece $\%$ C4\%9Finin-de\%C4\%9Ferlendirilmesi.pdf

Oktay, D., Rustemli, A., \& Marans, R. W. (2009). Neighborhood satisfaction, sense of community, and attachment: Initial findings from Famagusta quality of urban life study. ITU $A / Z$ Journal, 6(1), 6-20.

Panagopoulos, T., González Duque, J. A., \& Bostenaru Dan, M. (2016). Urban planning with respect to environmental quality and human well-being. Environmental Pollution, 208, 137144. https://doi.org/10.1016/j.envpol.2015.07.038

Parvin, A., Ye, A., \& Jia, B. (2007). Multilevel Pedestrian movement: does visibility make any difference? In 6th International Space Syntax Symposium (pp. 1-16), İstanbul.

Praliya, S., \& Garg, P. (2019). Public space quality evaluation: prerequisite for public space management. The Journal of Public Space, 4(1), 93-126. https://doi.org/10.32891/jps.v4i1.667

Project for Public Spaces. (Ed.). (2000). How to turn a place around: A handbook for creating successful public spaces. Project for Public Spaces Incorporated.

Rapoport, A. (1970). The study of spatial quality. Journal of Aesthetic Education, 4(4), 81-95. https://doi.org/10.2307/3331287

Read, S. (1999). Space syntax and the Dutch city. Environment and Planning B: Planning and Design, 26(2), 251-264. https://doi.org/10.1068/b4425

Roger Tym \& Partners. (2006). Physical regeneration investment framework (Newcastle, One NorthEast). http://www.ignite-ne.com/

Rowley, A. (1998). Private-property decision makers and the quality of urban design. Journal of Urban Design, 3(2), 151173. https://doi.org/10.1080/13574809808724423

Safari, H., \& Moridani, F. F. (2017). Syntactical analysis of the accessibility and sociability of a square in the Kuala Lumpur City Center. Frontiers of Architectural Research, 6(4), 456-468. https://doi.org/10.1016/j.foar.2017.06.005

Schulz, N. C. (1971). Existence space \& architecture. Studio Vista, Praeger Publishers Inc.

Shirvani, H. (1985). The urban design process. Van Nostrand Reinhold Company.

Sitte, C. (1889). City planning according to artistic principles (G. R. Collins, \& C. C. Collins, Trans.). Phaidon Press. (Original work published 1965)

Smith, T., Nelischer, M., \& Perkins, N. (1997). Quality of an urban community: a framework for understanding the relationship between quality and physical form. Landscape and Urban Planning, 39(2), 229-241.

https://doi.org/10.1016/S0169-2046(97)00055-8
Southworth, M. (1989). Theory and practice of contemporary urban design: A review of urban design plans in the United States. Town Planning Review, 60(4), 369-402.

https://doi.org/10.3828/tpr.60.4.x25357426v2h0431

Sternberg, E. (2000). An integrative theory of urban design. Journal of the American Planning Association, 66(3), 265-278. https://doi.org/10.1080/01944360008976106

Terzi, F., Akay, M., Erdem Okumuş, D., \& Gökçe, P. (2019). Re-coding the characteristics of public spaces: The case of İstanbul. ICONARP International Journal of Architecture and Planning, 7(2), 487-512. https://doi.org/10.15320/ICONARP.2019.95

Turner, A., Doxa, M., O'Sullivan, D., \& Penn, A. (2001). From isovists to visibility graphs: A methodology for the analysis of architectural space. Environment and Planning B: Planning and Design, 28, 103-121. https://doi.org/10.1068/b2684

Vadiati, N., \& Kashkooli, A. M. S. (2011). Environmental sustainability of newly developed city squares in historic cities: Case study of Isfahan-Iran. Procedia Engineering, 21, 829-837. https://doi.org/10.1016/j.proeng.2011.11.2084

Valipour, E., Mobaraki, A., Nikoofam, M., \& Tayyebisoudkolaei, S. (2019). Establishment of Space syntax to read and analyze urban network; the case of study, Famagusta city of Cyprus. Journal of Contemporary Urban Affairs, 3(1), 154-160. https://doi.org/10.25034/ijcua.2018.4692

Van der Geer, J., Hanraads, J. A. J., \& Lupton R. A. (2000). The art of writing a scientific article. Journal of Scientific Communications, 163, 51-59.

Van Nes, A., \& Yamu, C. (2018). Space Syntax: a method to measure urban space related to social, economic and cognitive factors. In C. Yamu, A. Poplin, O. Devisch, \& G. De Roo (Eds.), The virtual and the real in planning and urban design: Perspectives, practices and applications (pp. 136-150). Routledge, Taylor \& Francis Group.

https://doi.org/10.4324/9781315270241-10

Vandell, K. D., \& Lane, J. S. (1989). The economics of architecture and urban design: Some preliminary findings. Real Estate Economics, 17, 235-260. https://doi.org/10.1111/1540-6229.00489

Walzer, M. (1986). Pleasures and costs of urbanity. Dissent, 33, 470-475.

White, E. T. (1999). Path portal place: Appreciating public space in urban environments. Architectural Media.

Whyte, W. H. (1980). The social life of small urban spaces. The Conservation Foundation.

Whyte, W. H. (1985). The social life of small urban spaces. The Conservation Foundation.

Whyte, W. H. (1988). City: Rediscovering the centre. Doubleday.

Yeganeh, M., \& Kamalizadeh, M. (2018). Territorial behaviors and integration between buildings and city in urban public spaces of Iran's metropolises. Frontiers of Architectural Research, 7(4), 588-599. https://doi.org/10.1016/j.foar.2018.06.004

Zakariya, K., Harun, N. Z., \& Mansor, M. (2014). Spatial characteristics of urban square and sociability: A review of the city square, Melbourne. Procedia - Social and Behavioral Sciences, 153, 678-688. https://doi.org/10.1016/j.sbspro.2014.10.099

Zengel, R. (2007). Dönüştürülmüş Bir Meydan: Konak Meydanına Analitik Bir Yaklaşım. Mimarlık, 334, 40-43.

Zerouati, W., \& Bellal, T. (2019). Evaluating the impact of mass housings' in-between spaces' spatial configuration on users' social interaction. Frontiers of Architectural Research, 9(1), 34-53. https://doi.org/10.1016/j.foar.2019.05.005

Zucker, P. (1970). Town and square: From the agora to the village green. MIT Press. 